\title{
An Analysis of Novice Teachers' Questioning Types during the Microteaching Classroom
}

\author{
${ }^{1}$ Selvi Yuliani, ${ }^{2}$ Lilia Indriani \\ Universitas Tidar Magelang \\ *Corresponding Author \\ Email: indriani@untidar.ac.id
}

\begin{abstract}
This study aims to determine the query used by novice teachers during their micro-teaching practice in teaching Senior High School students. The researchers used qualitative methods in processing the data. The data obtained from the results of classroom observations with video zoom recording and documentation. The data sources for this study were taken from 10 novice teachers at one of the universities in Indonesia. The authors took the data to find out what the novice teachers used during they were doing micro teaching classroom. As a result, the types of question that the novice teachers used are procedural question, convergent question, and divergent question. With this research, it is hoped that it can be a correction for prospective teachers regarding questions that should be used to liven up the classroom atmosphere. All in all, the type of question that frequently uses is convergent question. The questions that novice teachers in teaching often use do not require high thinking.
\end{abstract}

Keywords: questioning types, classroom interaction, English teaching

\section{INTRODUCTION}

Good learning activities are the achievement of learning objectives in the classroom. However, this is often overlooked. For example, the teacher only gives lectures to the point that they do not know whether the student receives well what is said by the teacher. In overcoming this, the interaction between teachers and students is needed when learning takes place. It has aimed to determine student responses to student understanding of the material presented by the teacher. This interaction plays an essential role in classroom learning activities.

In connection with the current situation where the communication between teachers and students is often only one way, students only listen to what the teacher explains. Logically, this situation will make students forget about the previous lesson and will only remember what the teacher said about 5\%. It will be better if students can explain the material that the teacher has conveyed to others. Then the percentage can reach $90 \%$. This was conveyed by Coach Harry van de Wouw from TU/e University. This interaction is a significant point in teaching and learning activities because it can benefit both students and teachers. The teacher will get feedback that can be a measure of whether the material is well conveyed and received or not.

However, in reality, building interactions in class is still quite tricky. Some problems often arise, such as student difficulties in expressing what they want to say 
using English. Therefore the role of the teacher is significant in providing opportunities for students to develop their language. The teacher must build an excellent communicative learning atmosphere in practice in the classroom. Teachers can facilitate learning, but they must also be aware of how much and what kind of conversation they have to make.

Teachers have to manage their conversations during class. This is useful for building a balanced interaction between students and teachers. The teacher must be able to encourage students to talk more. Learning will be less suitable if teachers dominate the conversation in the classroom. Students must be more active in speaking than the teacher. Therefore, through questions, the teacher can encourage students to talk and open their minds. Most of the questions are presented to get answers, encouraging students to express their opinions. Besides encouraging students to be active in learning, questions can also increase student activeness. So, with questions from the teacher, students will be stimulated to answer these questions because not all students have the confidence to speak without being asked. So this is where the interaction between teachers and students occurs. However, maybe getting the attention or response from high school students is quite tricky. It requires several strategies to get student responses. Therefore, teachers must implement strategies that can make students feel enjoy being active in learning activities.

As Bowden and Ference (1998) have argued, teaching is not only about transferring knowledge to students, but teachers also need to be able to help students develop their knowledge. Developing knowledge can be done by asking students so that these students can think critically. Here, the role of questions can bring students into the material. According to Lockhart (1994), there are three types of questions that can do. The first is procedural questions. These questions usually appear when the teacher checks the assignment that has been given. This type of question can be based on student understanding to do the assigned task. The second is the convergent question. This question only requires a "yes" or "no" answer. Usually, this question is used to confirm previous information. Then the last one is a divergent question. This question encourages student responses to engage in higher-order thinking. So this question requires an answer that is not short.

Related to this, several studies have been carried out by several researchers, such as that conducted by Prabowo \& Alfiyanti (2013) with the title "An Analysis of Teachers' Questioning Strategies during Interaction in the Classroom: A case of the Eight Grade SMP PGRI 01 Semarang”. This study aims to determine the types of questioning strategies used by the teacher and determine how teachers use these question strategies. The problems faced by the teacher at that time were conditions in the classroom, such as how to control themselves, the interaction between teachers and students during learning that was less effective, and there were still many factors that came from the students themselves.

Then, another study was also carried out by A. Asnidewita (2015) in her research entitled, "An Analysis of Questions and Feedbacks of Teacher's Talk in Classroom Activities of SMPN 1 Enam Lingkung". This study aims to look at the types of questions and feedback the teacher uses when teaching. In this study, researchers also used the theory of Richard and Lockhart (1996), with the type of concurrent question that teachers most widely used. Meanwhile, in giving feedback, the teacher provides more praise to students. 
This research is different from previous research. This study only focuses on novice teacher strategies in asking and the types of questions that teachers often use. There was no previous study that discuss about it. This study aims to determine the types of questions that are often used by the novice teachers in the classroom, without investigating the feedback from these students. The research questions of this study are:

1. What types of questions that used by novice teachers in micro-teaching practice.

2. What type of question that frequently used by novice teachers in microteaching practice?

Classroom interaction is a reciprocal activity between teachers and students. In other words, it is included in social activities because between teachers and students or students with students. Therefore, there is a social communication or association. According to Homans (2004: 87), interaction is an event when an individual's activity against another individual is rewarded or punished by using an action by another individual who is his partner. According to Caudron (1988), the interaction between teachers and students is a basis for carrying out the learning process. So it can conclude that without the interaction between teachers and students, the teaching and learning process in class will never happen.

Giving questions is one of the things teachers always do in the teaching and learning process. This is one of the most common techniques that teachers use to control interactions in the classroom. The teacher gives questions to students for them to respond to. When they give feedback, there is an interaction in the class. Through inquiries, the teacher can discuss the essential elements of the material conveyed. By answering questions, students must use their logical thinking. A question can train students to think critically because everyone will think critically when faced with a question.

According to Dantonio and Beisenherz (2001), teachers must equip themselves with a series of logical and systematic questions that can sharpen students' perceptions, filter their thinking, and relate something unknown to something known. Thus, the key to effective learning is changing the role of the teacher from spreading knowledge as facilitators, counselors, and assessors. Instead, teachers can provide opportunities for students to express their opinions in order to train their self-confidence. In addition, teachers question function in classroom learning activities such as facilitating communication, stimulating thinking activities, strengthening conceptualization, assessing learning and many other functions. Therefore, the teacher must master the skills to ask question to students' level of ability.

\section{METHOD}

This research uses a qualitative approach. This type of research focuses on research objectives, namely to determine the types of questions often used by novice teachers at one of the universities in Indonesia. The data of this study came from teachers who were in the process of doing micro-teaching practice. The ten novice teachers came from one of the universities in Indonesia. Then, the instruments used in this study are observation sheets and videos of teaching practice. To obtain the data in this study, the authors observed and documented it. 


\section{Participants}

The participants used in this study were ten novice teachers in teaching practice during the micro-teaching courses. The authors chose their topic because, in this pandemic period, learning is done online so that interactions between teachers and students must be maintained in online learning activities, students must remain active. This is where the role of the questions given by the teacher is very important

\section{Instruments}

In achieving the objectives in this study, researchers collected data in various ways. In this study, the authors used two instruments, namely observation checklist and field notes. Observation checklist is used to observe the learning activities of each teacher. Then, Field notes are written notes obtained from the results of the hearing, observing, experiencing, and doing. This note is helpful as an intermediary between what is seen, heard, felt, touched with actual letters in the form of field notes. In this case, the writer uses field notes to write down what has been seen and heard while observing the teaching practice video.

\section{Data Analysis}

The researcher used four steps in analyzing the data about the types of questions. The first is transcript. From the observed teaching videos, the writer wrote down every question the teacher gave to the students. The second is categorization. After getting the data, the writer categorizes the questions into three types according to Lockhart (1994): procedural, convergent, and divergent. The third is counting. After the researchers writing the data, they write down the number of each type of question. The, the last is summarizing. The author makes a table from the results of categorizing and calculating the data obtained. Finally, the table is created by question type.

\section{RESULTS AND DISCUSSIONS}

After researching from 10 novice teachers at one university in Indonesia in the practice of micro-teaching in one teaching session, each lasting 20-30 minutes, several findings were found about the types of questions used by novice teachers through classroom observation and documentation. As stated by Richard and Lockhart, questions used by teachers are classified into three forms, namely procedural, convergent, and divergent. The table below will show the number of each question found.

Table 1. All types of question used

\begin{tabular}{cccc}
\hline Teacher & \multicolumn{3}{c}{ Question types } \\
\cline { 2 - 4 } & Procedural & Convergent & Divergent \\
\hline RF & 6 & 3 & 3 \\
\hline FA & 5 & 2 & 1 \\
\hline AF & 4 & 6 & 2 \\
\hline AA & 4 & 1 & 2 \\
\hline NH & 3 & 6 & 5 \\
\hline AL & 3 & 6 & 2 \\
\hline SH & 2 & 5 & 3 \\
\hline KA & 4 & 16 & 4 \\
\hline VD & 3 & 6 &
\end{tabular}




\begin{tabular}{cccc}
\hline AN & 5 & 7 & 2 \\
\hline Total & $39(31,17 \%)$ & $58(47,15 \%)$ & $26(21,13 \%)$ \\
\hline
\end{tabular}

As seen in the table, the number of each question used by the novice teacher is different. It means that there are questions that are often used by novice teachers. From 10 novice teachers in one teaching meeting for 20-30 minutes, there are 123 questions used. For the classification of these questions, there are 39 procedural questions, or it can be said that $32.7 \%$ of procedural questions are used by ten novice teachers. In one meeting, the average teacher uses 3 to 4 procedural questions. This question is often given to students at the beginning of learning, such as asking students how they are and their attendance, how are you today? And anybody is absent today?

Then, the second most frequently used question by novice teachers is the convergent question. From procedural and divergent questions, this question is most dominantly used by teachers. There are 58 questions out of 123 total questions found, or it can be said as much as $47.15 \%$. Teachers often use this question in the middle of learning. This is a question that requires a simple answer. For example, Do you know the topic for today? It used to ask questions about the topic to be studied. Do you get what I mean? It is used to ask students' understanding of what is explained by the teacher. The last one is a divergent question. Teachers rarely use this question. There were only 26 questions from 10 novice teachers during their one meeting, or it could be said that there were only $21.13 \%$. This question is a question that requires a more detailed/logical answer according to the opinion of the students. Can be seen as What do you think about narrative text? and Anyone can give an idea about narrative text? The example is used to ask students' opinions about something they already or may not know.

The choice of a novice teacher in teaching practice as a subject in this study is because they interact a lot with students through questions in the online classroom teaching practice. After getting the data through observing the teaching videos they made, the authors analyzed it and then grouped the questions into predetermined categories. For 20 to 30 minutes in one teaching practice meeting conducted by a novice teacher, 123 questions were found. Asking is an art of teaching that the teacher owns. Effective or not learning is seen from the ability to ask questions correctly. A teacher can find out some information from students that he cannot get through observation alone. With questions, the interaction between teachers and students will be dynamic. However, the questions asked must also be in accordance with the context or topic being discussed so that all students easily understand them.

Questions from teachers positively impact students, including increasing student activity or participation in classroom learning. Especially in this pandemic period, learning is done online. Students will tend to be passive if the teacher doesn't provoke them with a question. Then, questions can also make students think critically. In this case, the teacher can give the students the types of divergent questions to think broadly and creatively in answering them. The third is as the center of attention. Often occurs in the middle of learning, students are not focused or busy with other things. This makes the knowledge conveyed by the teacher less able to be absorbed by students and may not even be captured by students. Therefore, the teacher can provide convergent questions that aim to divert students' 
attention to the topic being asked. As a result, students become thinking about what is requested by the teacher. Then the fourth is to arouse students' curiosity. With the questions given by the teacher, students will usually compete to find answers. He didn't want his friend to get ahead in answering the questions.

Of the three types of questions, convergent questions are the most frequently used by teachers. This question requires short answers such as yes/no, yes/no so that students do not think deeply compared to divergent questions. This question usually aims to confirm students' understanding of the previous material. For example, Freeman and D. Larsen (1988) will quickly answer by using convergent questions because they do not need long answers. This will also increase students' confidence in class because the solutions required are simple, so students will not be afraid to answer questions from the teacher.

The number of convergent questions used is, of course, different. However, after being averaged from 10 novice teachers with findings of 58 questions out of 123 , it can be said that each teacher uses 5 to 6 convergent questions. It means that almost half of the question activities are carried out with convergent questions. In classifying the question whether the question is a convergent or open question, the author uses the theory of Richard and Lockhart (1994). His book entitled "Reflective Teaching in Second Language Classroom" states that convergent questions are questions that do not require many answers or do not require solutions that come from high thinking.

The following table will present the types of convergent questions used by novice teachers in interacting in the class.

Table 2. Convergent questions from the $1^{\text {st }}, 2^{\text {nd }}, 4^{\text {th }}$, and $7^{\text {th }}$ novice teacher

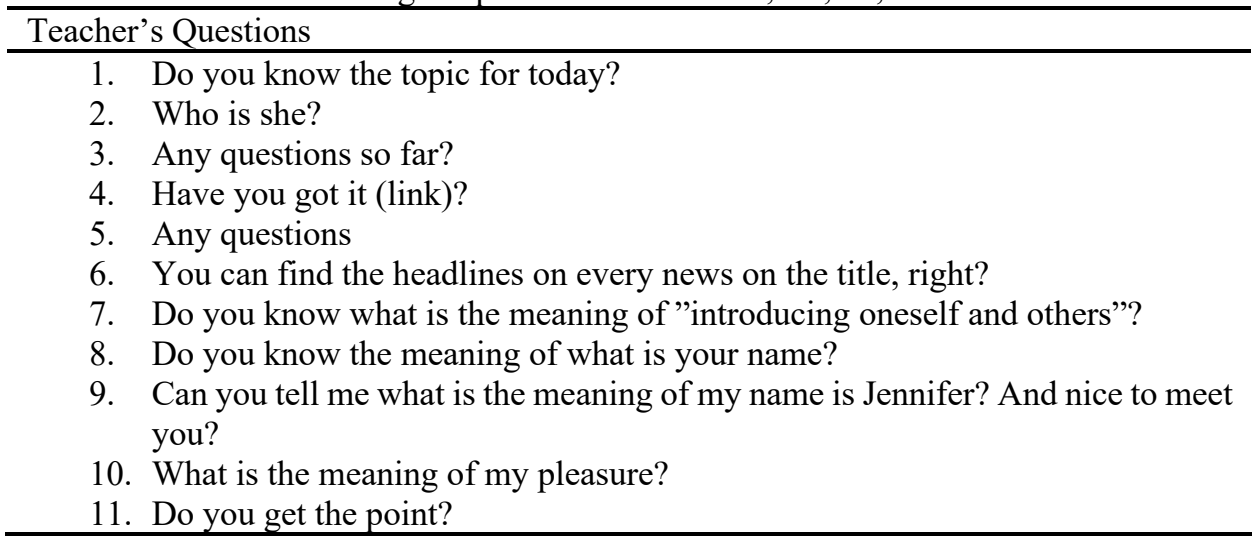

Based on the table above, teachers who use convergent questions are less than 6 , there are four teachers. They often use convergent questions with the aim of asking about their understanding of the material, whether they have understood it or not, or inviting students to ask questions. It can be seen in the table of questions 3,5 , and 11 . Then the second most frequently used question is a question that is used to ask the meaning of a sentence from English to Indonesian. This question is used to test their vocabulary knowledge as far as what vocabulary they have. That is the dominant question used by four teachers who use the fewest questions.

Here, six teachers use convergent questions in the category of many or more than 5 . The data will be presented in the following table. 
Table 3. Convergent questions from the $3^{\text {rd }}, 5^{\text {th }}, 6^{\text {th }}, 8^{\text {th }}, 9^{\text {th }}$, and $10^{\text {th }}$ novice teacher

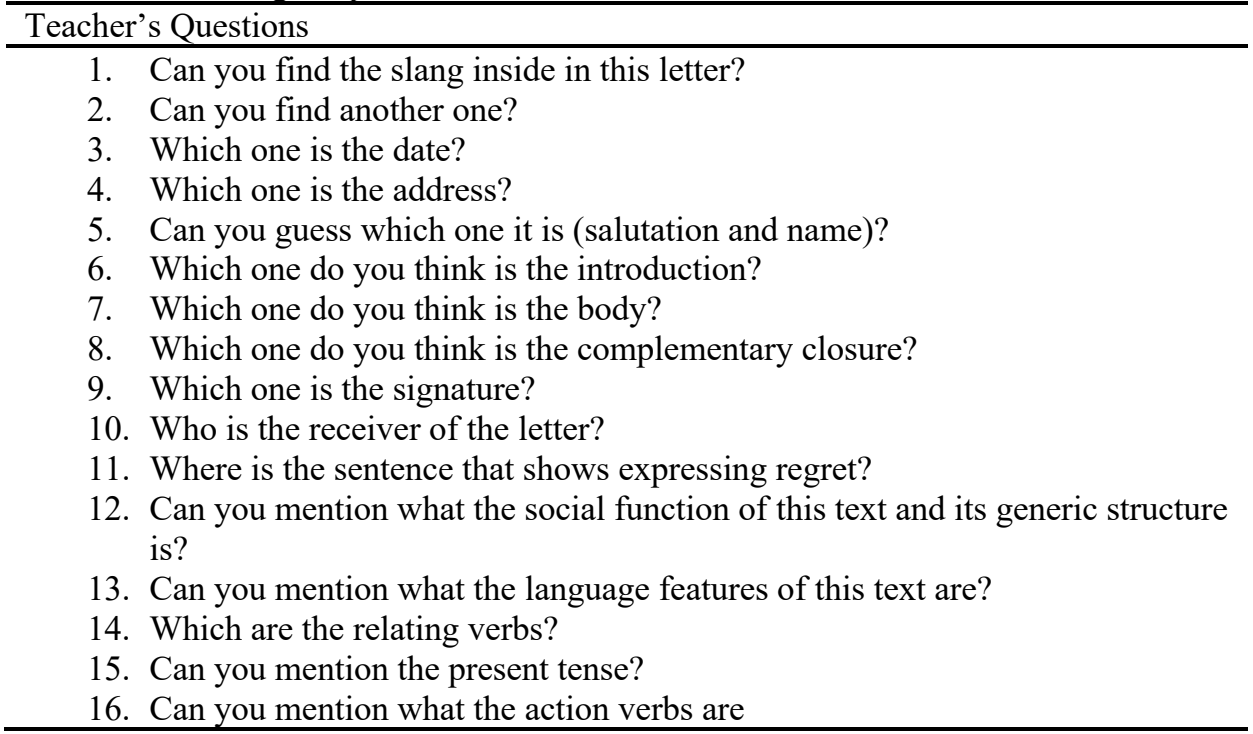

Based on the table above, obtained convergent questions from 6 teachers in many categories in using convergent questions. In this category, teachers more often use convergent questions as questions to ask part of the material being taught. In this case, students are required to find the parts contained in the letter. This includes convergent questions because students will find answers that are already available in the material presented and do not require higher-order thinking. In addition, students are also asked to mention the part of the material where the answer is already available. Students do not need to look for answers outside the material. They only focus on what has been explained by the previous teacher so that they can answer it easily.

In summary, all convergent questions used by ten novice teachers were used to relate students to the material being taught. However, there are various kinds of convergent questions that are used according to their purpose. The teacher uses these questions to check students' understanding before and after getting the material.

\section{CONCLUSION}

From the findings and discussions discussed in the previous paragraph, it can concluded that novice teachers use all types of questions, namely procedural, convergent, and divergent, in the practice of teaching microteaching. The total number of questions found was 123 questions. The translation is that there are 39 procedural questions or $31.7 \%, 58$ convergent questions or $47.15 \%$, and finally, there are 26 divergent questions or $21.13 \%$. So the most questions are divergent questions. Questions that novice teachers in teaching often use do not require high thinking.

\section{REFERENCES}

A.B. Prabowo K.A., R. A. (2013). An Analysis of Teacher's Questioning Strategies during Intersection in the Classroom: A Case of the Eight Grade SMP PGRI 01 Semarang. Vol. 4, No. 1, 40-53. 
Annisa, A (2019). The Power of Questioning: Teacher's Questioning Strategies in the EFL Classrooms. IRJE, Vol. 3, No 1, 91-106.

Ariani, N. R. (2018). Investigating the Types of Teacher Questions in EFL Secondary Classroom. Advances in Social Science, Education and Humanities Research, Vol. 276, 40-49.

Asnidewita. (2015). An Analysis of Questions and Feedbacks of Teacher's Talk in Classroom Activities of SMPN 1 Enam Lingkung. Repository UNP.

Bülent, D, E. B. (2016). An analysis of teachers' questioning strategies. academicJournals, Vol. 11(22), 2065-2078.

Ekawati, D. (2019). An Analysis of Teacher's Questioning Strategies During The Classroom Interaction at SMAN 4 Makassar. English Education Department Faculty of Teacher Training And Education Muhammadiyah University of Makassar. Thesis.

Inah, E. N. (2015). Peran Komunikasi dalam Interaksi Guru dan Siswa. Jurnal AlTa'dib, Vol. 8 No. 2, 150-167.

Kipper, H \& Tiia Ruutmann. (2010). Strategies and Techniques of Questioning Effectuating Thinking and Deep Understanding in Teaching Enginering at Estonian Centre for Enginering Pedagogy. Problem of Education the 21st Century, 19, 36-45.

Niza, A. K. (2017) An Analysis on Teachers' Questioning Strategies in Classroom Interaction. S1 thesis, Universitas Negeri Makassar.

Novianingsih, S (2015) An Analysis of the Question Types Used by the English Teacher in SMAN 1 Kayen Pati in Academic Year 2014/2015. thesis, Fakultas Keguruan Dan Ilmu Pendidikan

Omari, H. A. (2018). An Analysis of the Types of Classroom Question which Jordanian English Language Teachers Ask. Modem Applied Science. Vol 2(04).

Rismayanti. (2018). An Analysis of Teacher's Questioning Strategies during the Classroom Interaction at PIBA of UIN Alauddin Makassar. Pendidikan in English Education Department of Tarbiyah and Teaching Science Faculty of UIN Alauddin Makassar. THESIS.

Rosyidah, K. (2018). An Analysis of Teacher's Questions Used in Classroom Interaction at 11th Grade of SMK Ma'arif NU Prambon-Sidoarjo. THESIS.

Wildan, A. \&. (2017). Analisis Ragam Pertanyaan dan Strategi Bertanya Guru dalam Pembelajaran Bahasa Indonesia di SMPN 8 Banda Aceh. Master Bahasa, Vol. 5 No. 1, 63-74.

Yusriati, D. R. (2019). An Analysis of Teacher's Questioning Strategies in English Classroo: A Case Study at SMK Negeri 4 Medan. 1066-1078.

Ziarah. (2020). An Analysis of Teacher's Questioning Strategies during the Classroom Interaction. English Education Program Faculty of Education and Teacher Training State Islamic University Sulthan Thaha Saifuddin Jambi. Thesis. 